\title{
The Study of African Leave (Vernonia amygdalina) in for Improving the Quality of Local Duck Meats of West Sumatera
}

\author{
Zasmeli Suhaemi $^{1)}$, Zulkarnaini $^{1)}$, Afrijon ${ }^{1)}$, PN Jefri ${ }^{1{ }^{1}}$ \\ ${ }^{1)}$ Animal Husbandry Department, Faculty of Agriculture, Universitas Taman \\ Siswa, Indonesia \\ Email: $\underline{\text { emizasmeli@gmail.com }}$
}

\begin{abstract}
This research purpose to observe the response of local duck, especially male duck that given African Leaf Flour (ALF) in the diet, toward body weight and blood cholesterol content. The treatment for this research will be given by differentiate the ALF level in five levels $(0 \%, 0.5 \%, 1.0 \%, 1.5 \%$, and $2.0 \%)$ with four times replication. This research used Completely Randomized Design. This treatment is obsessed to 80 male ducks which are rearing from the age of 4 until 10 weeks. The result showed that the increasing of ALF level in diets, will highly significant increase the body weight growth (BWG) of duck, as the increasing value of $\mathrm{BWG}$ is $23.59 \%(\mathrm{P}<0,01)$, and its similarly with the Feed Conversion Ratio (FCR). The blood cholesterol content is decreasing to $7.41 \%$ for $1.5 \%$ the ALF level given $(\mathrm{P}<0,01)$, while the content of cholesterol-HDL and LDL has not significantly $(\mathrm{P}>0,05)$. However, the content of cholesterol-HDL in blood tend to increase along with the increasing of the ALF level given. Utilization of ALF level until $2.0 \%$ could increase the quality of local duck meat, because its produce higher meat production and improve the content of cholesterol for creating healthy animal food sources.
\end{abstract}

Keywords : Vernonia amygdalina, local duck, west sumatera, healthy food

\section{Introduction}

The genuineness of germplasm should be preserved as an attempt of supply of germ on advanced cultivation. The existence of germplasm of local duck in West Sumatera is slowly decreasing, and yet there is no attempt for its conservation consistently and frequently. The extinction of germplasm diversity could never be replaced even by advances of biotechnology, at least until now. One genetically approach for the advancement of duck genetic quality is through selection, the high quality of germ selection and a precise breeding system can create high productivity descent.

A ration is an important one in the animal husbandry field because it is covering about $70 \%$ of total cost production (7). A ration is an important component of the breed, as it is including $70 \%$ of cost production. Breeding of duck commercially, generally is needed ration importation, the nutritional content, and extra feed. Local duck production also depended on its ability as natural or genetics. The other local duck superiority is their capability on using the feed with low quality so it can reduce the cost of feed, bad environment, and its resistant of disease compared to chickens. 
Cholesterol is an important amphipathic lipid on an arrangement of permeability and membrane fluidity, and also an outer layer of plasma lipoprotein (2). Lipids are consist of triglycerides (neutral fat), phospholipids (lecithin), and cholesterol (3). However, the high levels of cholesterol in duck blood often become limiting factors for the consumer to cut or even not at all consuming duck husbandry product. Excessive cholesterol in the human body will be buried in the walls of blood vessels and cause a condition called atherosclerosis where there is a narrowing of blood vessels. This condition is the forerunner of the occurrence of heart disease and stroke in consumers who consume the duck meat (5). Cholesterol contents can be influenced by fat mussel contents and type of meat fibers (9), also genetics and environments (6).

African leaf is a plant that has so many benefits for health, which is as antihypertensive, antidiabetic, antimicrobial and analgesic (10). The many benefits of African leaves are inseparable from its antioxidant. African leaves consist of various secondary metabolites. It is known that extract of African leaves contains of components of sugar, polyphenolic, terpenoids, saponins, alkaloids, glycosides, steroids or triterpenes, anthraquinones and coumarin without cyanogenic. But only tannins, glycosides and saponins without flavonoid can be obtained from the roots and stems of African leaves skin. In addition, phenolic compounds that have been identified in African leaves are included in flavonoid groups (4). Also, African leaves have proved to consist of high levels of antioxidant, and various bioactive substances that can improve health (10).

Research using African leaves in mice has been shown to reduce lipid content, cholesterol, triglycerides, K-HDL and K-LDL (1). Those showed that African plants are expected able to reduce cholesterol contents of duck products, then diminishing the limiting factors to society that want to consume duck meats or eggs. This study aims to examine the use of African leaves as feeds for local duck additives for body weight gain, and the blood cholesterol content of male local ducks.

\section{Experimental Section}

This study uses 80 local ducks at the age of 4 weeks, that have been cared on the shed with battery systems until the age of 12 weeks. The usage of African leaves is done in the form of flour. African leaves that have big enough will be dried in the sun until dry and destroyable, then until finely grounded and sieved with $1 \mathrm{~mm}$ sieve size.

The ration used is standardized ration that consists of 124 concentrates, grounded corn, and fine bran. Along with the contents of $16.14 \%$ crude proteins, and $2685 \mathrm{Kcal} / \mathrm{kg}$ of the energy of ration (Table 1 ).

Table 1. The contents of food substances of the ration ingredients

\begin{tabular}{lrrcc}
\hline \multicolumn{1}{c}{ Food Substance } & Fine Bran & Corn & Concentrate & $\begin{array}{c}\text { African Leaves } \\
\text { Flour }\end{array}$ \\
Dry ingredients (\%) & 90,70 & 91,29 & 89,63 & 90,00 \\
Crude Protein (\%) & 11,19 & 8,60 & 31,00 & 18,48 \\
Crude Fiber (\%) & 17,63 & 3,37 & 5,00 & 16,70 \\
Crude Fat (\%) & 4,00 & 2,60 & 3,00 & 1,68 \\
ME (kkal/kg) & 1630 & 3420 & 2600 & 291,60 \\
\hline
\end{tabular}

56 IEKSAKTA: Berkala IImiah Bidang MIPA 
Sources : Suhaemi, Abbas and Uddin (2016)

*Result of laboratory analysist of Payakumbuh Politani (2018)

The research program is RAL (Completed Random Program) with 5 treatments of African leaves flour $(0 \%, 0.5 \%, 1.0 \%, 1.5 \%$ and $2.0 \%)$, every treatment will repeated for 4 times. The significant analysis result will be continued using the test of Dunkan Multiple Comparison.

The variable analyzed on this study are the performance of male ducks as a broiler and the contents of lipid components of duck blood that contain a total of cholesterol (TK), triglycerides (Tgs) and K-HDL.

\section{Results and Discussions}

The resulting study of Body Weight, Growth of body weight and the ration conversion shown in Table 2. The average of live weights of male local ducks showed that the increase of the treatment of African leave flours in the ration will increase the average of live weights, so is increasing on the average of body weights. Also, the treatment of African leave flours can decrease the ration conversion on male ducks.

Table 2. The average of Live Weight, Body Weight Growth, the ration conversion

\begin{tabular}{ccccccc}
\hline Treatment & BH $(\mathrm{g})$ & $S-d e v$ & PBB $(\mathrm{g})$ & $S-d e v$ & Conversion & $S$-dev \\
\hline $0,0 \%$ TDA & $1393,5^{\mathrm{a}}$ & 6,95 & $651,1^{\mathrm{a}}$ & 19,82 & $7,8^{\mathrm{a}}$ & 0,22 \\
$0,5 \%$ TDA & $1395,0^{\mathrm{a}}$ & 19,85 & $661,7^{\mathrm{a}}$ & 20,79 & $7,6^{\mathrm{a}}$ & 0,24 \\
$1,0 \%$ TDA & $1428,0^{\mathrm{b}}$ & 86,86 & $673,7^{\mathrm{a}}$ & 22,73 & $7,5^{\mathrm{a}}$ & 0,25 \\
$1,5 \%$ TDA & $1503,6^{\mathrm{b}}$ & 49,89 & $687,2^{\mathrm{a}}$ & 15,47 & $7,3^{\mathrm{a}}$ & 0,17 \\
$2,0 \%$ TDA & $1511,8^{\mathrm{b}}$ & 60,54 & $804,7^{\mathrm{b}}$ & 23,95 & $6,3^{\mathrm{b}}$ & 0,19 \\
\hline
\end{tabular}

The different superscript in the same column showed significantly different $(\mathrm{P}<0.5)$

The various result analysis of live weight of ducks, body weight growth, and ration conversion conclude significantly different $(\mathrm{P}<0.01)$. Based on an advanced test, the results showed that the treatment of African leave flours on $2.0 \%$ levels significantly different with the treatment with less of African leave flours. Those occur because the African leave contained bioactive and antioxidant substances (Yeap, et al., 2010), thus can raise livestock health's and growth as well as more efficient in feed consumed. The total contents of cholesterol, triglycerides, and HDL cholesterol is showed on Table 3.

The result on table 3 reveals that the increase of African leave flours treatment in ration will decrease the average of TK and TGS although it is rising up again on the $2.0 \%$ level, that there is not significantly different $(\mathrm{P}<0.05)$. The contents of HDL cholesterol also tend to increase along with the increasing of African leave flours treatment, but the various result analysis concluded not significantly different $(\mathrm{P}<0.05)$. Those are showed that the treatment of African leave flours has a probability to produce low cholesterol duck products, and increased K-HDL. As shown before, that TK consists of LDL cholesterol and HDL cholesterol, which is HDL cholesterol

57 IEKSAKTA: Berkala IImiah Bidang M IPA 
known as good cholesterol, which is not harmful to the human body because of its ability to throw away the excess of bad cholesterol (K-LDL) in the arteries back to the liver (3).

Table 3. The content of total cholesterol (TK), HDL cholesterol (K-HDL) and triglycerides of duck blood

\begin{tabular}{ccccccc}
\hline Treatment & TK & S-dev & K-HDL & S-dev & TGS & S-dev \\
\hline 0,0\% TDA & 184,4 & 3,61 & 81,6 & 1,30 & $131,0^{\mathrm{a}}$ & 19,41 \\
0,5\% TDA & 175,5 & 2,41 & 82,0 & 4,08 & $119,2^{\mathrm{b}}$ & 13,80 \\
$1,0 \%$ TDA & 172,2 & 0,92 & 83,5 & 4,54 & $111,0^{\mathrm{b}}$ & 3,12 \\
$1,5 \%$ TDA & 170,7 & 9,30 & 83,1 & 2,44 & $110,7^{\mathrm{b}}$ & 6,53 \\
2,0\% TDA & 184,2 & 3,68 & 83,6 & 0,93 & $122,6^{\mathrm{a}}$ & 3,67 \\
\hline
\end{tabular}

\section{Conclusion}

The treatment of flour from African leaves in male local ducks feed as a broiler, can increase the body weight growth and decreased the ration conservation until $2.0 \%$ levels, then decreased the total blood cholesterol contents, and its triglycerides thus will increase the contents of HDL cholesterol that known as good cholesterol. The recommended application based on this result study is on $1.5 \%$ levels because it produced the lowest TK and TGS and the highest K-HDL.

\section{References}

[1] Adaramoye, O. A., Akintayo, O., Achem, J., \& Fafunso, M. A. (2008). Lipidlowering effects of methanolic extract of Vernonia amygdalina leaves in rats fed on high cholesterol diet. Vascular Health and Risk Management, 4(1), 23541.

[2] Botham, KM., \& Mayes, PA. (2012). Harper's IllustratedBiochemistry: Cholesterol Synthesis, Transpor \& Excretion. Amerika Serikat: McGraw Hill.

[3] Garaha, K. C. (2010). Kolesterol. Jakarta: PT Elex Media Komputido.

[4] Ii, E., Zaman, K., \& Das, A. (2017). Effect of Extracts of Vernonia Amygdalina in Helminthiasis- A Tropical Neglected Disease. Open Access Journal of Pharmaceutical Research, 1(8).

[5] Ma, H. (2006). Cholesterol and Human Health. The Journal of American Science, 2(1), 46-50.

[6] Murray, K. R., Granner, K. D., Mayes, P. A., \& Rodwell, V. W. (2000). Harper's Biochemistry 20th Ed. USA: Appleton and Lange.

[7] Pal, V., Gobade, M., Kanth, K., Thakur, A., \& Maini, S. (2013). COMPARATIVE EFFICACY OF SUPPLEMENTATION OF HERBAL LIVER TONIC PRODUCTS ON GROWTH AND PERFORMANCE IN BROILERS. International Journal of Advanced Scientific and Technical Research, 6(7). 
[8] Suhaemi, Z., Abbas, M. H., \& Uddin, Z. (2016). Potency of Local Duck in West Sumatera for Food Security. GRJA, 5(10), 2015-1016. https://doi.org/10.15373/22778160

[9] Thu, T. N., Leslie, D., Thompson, D., Michael, L., Galyean, J., Brooks, C., ... Patterson, L. (2011). In: Mallory Boylan. Comprehensive Reviews in Food Science and Food Safety. Australia: John Wiley \& Sons, Inc .

[10] Yeap, S. K., Ho, W. Y., Beh, B. K., Liang, W. S., Ky, H., Hadi, A., Alitheen, N.B. (2010). Ethnomedical Used Green Vegetable With Multiple BioActivities.Journal of Medicinal Plants Research, 4(25), 2787-2812. 